\title{
Two new species of Passalus Fabricius (Coleoptera: Passalidae) from the western Brazilian Amazon with comments on the taxonomic limits of the subgenera
}

\author{
Marcus Bevilaqua ${ }^{1,2}$ \& Claudio Ruy Vasconcelos da Fonseca ${ }^{1,3}$ \\ ${ }^{1}$ Instituto Nacional de Pesquisas da Amazônia (INPA), Coordenação de Biodiversidade (CBI0), \\ Laboratório de Sistemática e Ecologia de Coleoptera (LASEC). Manaus, AM, Brasil. \\ ${ }^{2}$ ORCID: http://orcid.org/0000-0003-2863-5115. E-mail: marcusbevilaqua@gmail.com \\ ${ }^{3}$ ORCID: http://orcid.org/0000-0002-1955-288X. E-mail: rclaudio@inpa.gov.br
}

\begin{abstract}
Passalus Fabricius, 1792 is the largest genus of Passalidae and presents great diversity in South America, mainly in the Amazon region. Currently this complex and heterogeneous genus is subdivided into three subgenera: P. (Pertinax) Kaup, 1869, P. (Mitrorhinus) Kaup, 1871, and P. (Passalus). Herein, two new species of Passalus from the western region of the Brazilian Amazon, a diverse but poorly studied area, are described and illustrated. The new species Passalus (Pertinax) deuterocerus sp. nov. and Passalus (Passalus) cleidecostae sp. nov. are compared with similar species occurring in nearby regions. Also, the diagnostic characters used to define the subgenera and sections of Passalus are summarized.
\end{abstract}

Key-Words. Acre; Neleus; Passalinae; Pertinax; Saproxylophagous beetles.

\section{INTRODUCTION}

Passalus Fabricius, 1792, the largest of the 64 genera of Passalidae, is exclusively Neotropical with about 139 valid species (Schuster \& Cano, 2008), being dominant in the bess beetle fauna of South America. Currently, the genus is divided into three subgenera: P. (Pertinax) Kaup, 1869, P. (Mitrorhinus) Kaup, 1871, and P. (Passalus) which, in turn, is subdivided into three species groups, the "sections": Phoroneus, Petrejus and Neleus (Luederwaldt, 1931; Hincks \& Dibb, 1935, 1958). The three subgenera differ mainly by the number of secondary mediofrontal tubercles on the anterior frontal edge (Luederwaldt, 1931). Boucher (2015a) proposed the revalidation of seven genera previously synonymized with Passalus, including Pertinax, without use of cladistic methods. However, we prefer to maintain the classification previously proposed by Luederwaldt (1931) and enhanced by Hincks \& Dibb $(1935,1958)$, since it is the most used by Passalidae researchers.

According to Fonseca \& Reyes-Castillo (2004), 26 species of Passalus occur in the Brazilian Amazon. Recently, Bevilaqua \& Fonseca (2019) published a knowledge synthesis of the Passalidae for the west-most region of the Brazilian Amazon, and established five new records for Passalus species, increasing the total number to 31 . In a new evaluation of the material coming from this rich area, it was verified the existence of two new species, here described and illustrated.

\section{MATERIAL AND METHODS}

The studied material belongs to the invertebrate collection of the Instituto Nacional de Pesquisas da Amazônia, Manaus, Brazil (INPA) and Coleção Zoológica Professor Paulo Bührnheim of the Universidade Federal do Amazonas, Manaus, Brazil (CZPB).

The images were obtained in Leica M165C stereomicroscope with a coupled DFC295 camera and processed in the LAS version 4.2 software to perform the morphometric measurements. Then, they were stacked in layers by the software Helicon Focus version 5.3 in order to generate a single image of combined focus. For uniform and more effective illumination, we used the geodesic dome of lighting according to Kawada \& Buffington (2016). The images were edited in Adobe Lightroom ${ }^{\circledR}$ Software for light and contrast correction, and the plates were made using Adobe Photoshop ${ }^{\circledast}$. The labels data of the exam- 
ined material were transcribed in verbatim. A slash (/) indicates a new line on the label, additional information are given in square brackets ([ ]).

The terminology for the cephalic capsule and mandibles follows Boucher (2006) with the addition of the structure "cephalic nodule" = "mamelão" sensu Luederwaldt (1931); other parts of the body follow Reyes-Castillo (1970). The classification of the family follows Fonseca et al. (2011), while the classification of Passalus follows Luederwaldt (1931), Hincks \& Dibb (1935, 1958) and Reyes-Castillo (1970).

\section{RESULTS}

\section{Passalus (Pertinax) deuterocerus sp. nov.} (Figs. 1, 2, 3A, B, C)

Type material: HOLOTYPE: o" (INPA). "BRAZIL: Acre: Cruzeiro do Sul / BR 364 Sítio Rosalvo / 0803'36.68"S, 72²3'18.48"W / 05-11.ix.2011 / Fernando Pinto, Gleic Sá col”. PARATYPES: “Cruzeiro do Sul / BR 364 Sítio Rosalvo / 08 $03^{\prime} 36.68^{\prime \prime}$ S, 72²3'18.48"W / 05-11.ix.2011 / Fernando Pinto, Gleic Sá col. (1 $\sigma^{\prime \prime}, 4$ ㅇ, INPA). Cruzeiro do Sul / BR 364 Sítio Rosalvo / 0803'37.09"S, 72²3'18.29"W / 05-11.ix.2011 / Fernando Pinto, Gleic Sá col. (1 \&, INPA). Cruzeiro do Sul / 05-15.iv.1981 / F.G. Mello col. (1 \&, INPA). Feijó / [Ramal] Deusa - Interflúvio Envira/Purús / 08³0'20.98"S, 7002'41.43"W / 05-11.ix.2011 / Fernando Pinto, Gleic Sá col. (1 ơ', 1 \%, INPA). Feijó / [Ramal] Deusa Interflúvio Envira/Purús / 08³0'32.41"S, 7002'47.77"W / 05-11.ix.2011 / Fernando Pinto, Gleic Sá col. (1 ơ, 2 \%, INPA)."

Diagnosis: medium sized specimens $(22-25 \mathrm{~mm}$ total length); body convex; anterior frontal edge straight or slightly convex coarsely punctated; posterior mediofrontal area with large and rounded cephalic nodule; latero + mediofrontal tubercles large and conspicuous, with acute apices attached to inner tubercles (which are larger and with rounded apices) by weak anterofrontal ridges; small secondary mediofrontal tubercles, smaller than the latero + mediofrontal tubercles, with acute apices, near to each other; secondary laterofrontal tubercles nearly inconspicuous with slightly obtuse apices; posterofrontal ridges strong, elevated and straight, attached to the central tubercle, which is small, flat, with only apex pronounced; lateroposterior tubercles conspicuous and transverse; mentum with a dilated mediobasal area and large, deep lateral scars; anterior angles of pronotum acute and protruded; mesosternal scars shallow, triangular-shaped, with opaque surface and presence of micro bristles; metasternal disc barely delimited, with group of punctures in posterior region; metasternal lateral grooves narrow and glabrous; aedeagus elongated and narrow, median lobe elongated, larger than basal piece and parameres together, containing two sclerotized plates (ventral view); parameres separated from basal piece by conspicuous suture (ventral view).

\section{Description}

Body (Figs. 1-3): convex; size: medium (22-25 mm, total length).

Head (Figs. 1A-C, 2A-B, 3A-B): Labrum: straight anterior border. Clypeus: hidden under frons, with anterior angles large, acute and positioned between latero + mediofrontal and secondary laterofrontal tubercles, visible in dorsal view; lateroclypeal pits deep. Anterior frontal edge: straight, sometimes slightly convex and narrow. Secondary mediofrontal tubercles: small, smaller than the latero + mediofrontal tubercles, with acute apices, near to each other. Latero + mediofrontal tubercles: large, conspicuous, with acute apices, projected forward. Secondary laterofrontal tubercles: small, almost inconspicuous, with obtuse apices. Mediofrontal area: caliciform 2.1× wider than long, shallow; with coarse punctures, scattered over anterior region, and an inconspicuous longitudinal groove between secondary mediofrontal tubercles. Cephalic nodule: large, wellmarked, rounded. Inner tubercles: large, conspicuous, with rounded apices, slightly larger than latero + mediofrontal tubercles, slightly near to each other than to the central tubercle. Anterofrontal ridges: straight, small, weak, sometimes inconspicuous. Posterofrontal ridges: elevated, strong, nearly straight, starting at apex of central tubercle. Central tubercle: conical, flat, with apex not free and dilated posteriorly. Lateroposterior tubercles: conspicuous, transverse, slightly distant from central tubercle, with evident apex. Laterofrontal areas: slightly deep and rough, surface with a few stretch marks. Lateropostfrontal areas: deep, with rough surface. Postfrontal area: shallow, smooth surface. Postfrontal groove: well-marked, lacking medial notch. Epicranial sutures: well-marked. Epicranial pits: deep. Anterior angles of head: well-developed, with acute apices, slightly smaller than latero + mediofrontal tubercles. Canthus ocular: apices almost straight, not reaching half of eye. Antennae: trilamellated, with small, robust lamellae, distal lamella wider than other two.

Mouthparts (Figs. 2B, 3B): Ligula: tridentate, median tooth larger, narrower than lateral teeth. Hypostomal process: wide, glabrous, slightly close to mentum. Mentum: mediobasal area: dilated, smooth, glabrous, with slightly protruded anterior region lacking median notch; lateral lobes with apices externally rounded and slightly straight at the inner face; lateral scars large, deep, glabrous, unpunctate, rounded, sometimes slightly oval. Mandibles: incisor lobe with three well-formed apical teeth; suprainternal teeth robust; infrabasal pits inconspicuous. Maxillae: lacinia bidentate at apex.

Prothorax: Pronotum (Figs. 1A, C, 2A, C): anterior edge slightly straight; anterior angles acute and protracted; marginal groove well-marked, deep, narrow, and punctate throughout, with apex dilated, reaching more than $1 / 3$ of pronotal width; lateral fossae large, well-marked, deep and rounded, with group of coarse punctures. 
Prosternum (Fig. 1B): prepisternum with a few long, sparse setae on outer face; prepimerum with a few sparse bristled punctures; prosternelum rhomboidal, with acute base.

Mesosternum (Figs. 1B, 2D, 3B): smooth, glabrous; mesosternal scars triangular-shaped, shallow, with opaque surface containing micro bristles, without punctures or pubescence.

Metasternum (Figs. 1B, 2E, 3B): disc barely delimited, more dilated than lateral regions; punctation forming group of punctures on lateroposterior region; pubescence absent; lateral groove narrow, thinner than mesotibiae, deep, without punctures or bristles.

Elytra (Figs. 1A, C): approximately $2.5 \times$ longer and $1.1 \times$ wider than pronotum; striae narrower than interstriae, marked by circular and inconspicuous punctures on dorsal striae, well-defined in lateral striae; epipleura and humeri glabrous.

Legs (Figs. 1A-C, 2A, C, E): profemur with well-marked groove on anteroventral border not reaching apex; posteroventral border with a few setae near apex; protibiae not dilated; mesotibiae with one or two small spines on outer face; metatibiae with one small spine on outer face.

Abdomen (Fig. 1B): sternite VII with incomplete and well-marked groove; sides rough.

Aedeagus (Fig. 2F): Median lobe: narrower than parameres, almost as long as parameres and basal piece together; ventrally with two lateral sclerotized plates lacking at median region. Basal piece separated from parameres by distinct suture. Parameres ventrally, with median anterior region with central emargination; laterally, with rounded projections almost reaching half of median lobe length; dorsally, with unjoined projections. Basal piece ventrally, short, with convexity in posteromedian region; dorsally lateral projections separate.

Etymology: The specific epithet derives from the union of two Greek words, "deúteros" ("secondary" or "double") and "keros" ("horn" or "any hornlike projection"), in reference to the two secondary mediofrontal tubercles, the most remarkable feature of the species.

Polymorphisms: The secondary mediofrontal tubercles may vary in size and distance from each other; the anterofrontal ridges may be almost absent in some specimens.

Remarks: Due to the convex body, well-developed inner tubercles, barely delimited metasternal disc, and metasternal pubescence absent, Passalus deuterocerus sp. nov. is assigned to the subgenus Passalus (Pertinax). It is very similar to P. latifrons Percheron, 1841, P. morio Percheron, 1835 , and especially to $P$. epiphanoides (Kuwert, 1891). The differences between $P$. deuterocerus sp. nov. and $P$. latifrons are more pronounced because the new species has small- er size, two secondary mediofrontal tubercles, mesosternal scars, and absence of pubescence on posterior region of the pronotum ventrally, while P. latifrons is larger, has no secondary mediofrontal tubercles or mesosternal scars, and has pubescence on the posterior region of the pronotum ventrally (Table 1). Passalus deuterocerus sp. nov. differs from P. morio by having acute latero + mediofrontal tubercles (obtuse in P. morio), anterior frontal edge of the head thinner (which is thicker in P. morio), presence of secondary mediofrontal tubercles (absent in P. morio), and by the general shape of aedeagus (Table 1). When comparing the new species with P.epiphanoides, the differences are more subtle and require attention. Reyes-Castillo (1973) redescribed P. epiphanoides adding some characters as interspecific variations, such as protruding edges of the median notch of the anterior frontal edge of the head forming two secondary mediofrontal tubercles and mesosternal scars, which may be presented as two triangular-shaped matte areas covered with submicroscopic spicules. However, a reexamination the specimens studied by Bevilaqua \& Fonseca (2019) showed that these features are constant in series of specimens. A better analysis showed that these so-called polymorphic characters are diagnostic features that distinguish the two species. Thus, $P$. deuterocerus sp. nov. can be differentiated from P. epiphanoides by the narrower mediofrontal area (Fig. 3A); two secondary mediofrontal tubercles (Fig. 3A); mediobasal area of the mentum with rounded anterior region, without punctures or bristles (Fig. 3B); shallow mesosternal scars with slightly triangular shape with matte surface and presence of micro bristles (Fig. 3C); metasternal disc with a group of punctures on the lateroposterior region (Fig. 3C); narrower aedeagus, with median lobe with narrower sclerotized plates, parameres with median anterior emargination and basal piece with concavity at posterior edge. Passalus epiphanoides presents wider mediofrontal area (Fig. 3D), absence of secondary mediofrontal tubercles (Fig. 3D), mediobasal area of the mentum may have punctures or bristles and a notch in the anterior region (Fig. 3E), deep and oval or drop shape mesosternal scars with matt surface and presence of micro bristles (Fig. 3F), metasternal disc with a small group of punctures in the lateroposterior region (Fig. 3F), wider aedeagus, with median lobe with wider sclerotized plates, parameres with median convexity on the anterior edge and basal piece with convexity on the posterior edge.

The main difference between $P$. deuterocerus sp. nov. and other species currently allocated in $P$. (Pertinax) is the presence of secondary mediofrontal tubercles, a characteristic that apparently belongs to the Rhodocanthopus group. However, other characters such as eyes reduction, presence of secondary inner tubercles and presence of large spines on the external face of the meso- and metatibia, besides the general shape of the aedeagus (JiménezFerbans et al., 2016a), do not allow the new species to be allocate in this group. Furthermore, it seems to be more related to species belonging to $P$. (Pertinax) s. str. such as $P$. morio, $P$. latifrons, $P$. epiphanoides and $P$. convexus Dalman, 1817. However, phylogenetic analysis that is in process may have clarified this issue further. 
Table 1. Differential characters of Passalus deuterocerus sp. nov., P. morio Percheron, 1835, P. latifrons Percheron, 1841 and P. epiphanoides (Kuwert, 1891).

\begin{tabular}{|c|c|c|c|c|}
\hline Characters/Species & P. deuterocerus sp. nov. & P. morio & P. Iatifrons & P. epiphanoides \\
\hline $\begin{array}{l}\text { Frons, secondary mediofrontal } \\
\text { tubercles }\end{array}$ & $\begin{array}{l}\text { Two, well developed, with sharpened } \\
\text { apices close to each other. }\end{array}$ & Absent & Absent & Absent \\
\hline Frons, latero + mediofrontal tubercles & Acute & Obtuse & Acute & Acute \\
\hline Clypeus, anterior angles & Large and visible in dorsal view & Small and not visible in dorsal view & Small but visible in dorsal view & Small but visible in dorsal view \\
\hline Frons, anterofrontal ridges & Usually present, but weak & Usually present, but weak & Absent & Absent \\
\hline Vertex, lateroposterior tubercles & Large, transversal, very evident & Large, transversal, very evident & Large, slightly triangular, very evident & Small, slightly triangular, very evident \\
\hline Mentum, mediobasal area & $\begin{array}{l}\text { Dilated, without punctures, bristles or } \\
\text { notch on anterior region }\end{array}$ & $\begin{array}{l}\text { Not dilated, with punctures, bristles } \\
\text { and notch on anterior region }\end{array}$ & $\begin{array}{l}\text { Not dilated without punctures, bristles } \\
\text { or notch on anterior region }\end{array}$ & $\begin{array}{l}\text { Dilated, with punctures, bristles and } \\
\text { notch on anterior region }\end{array}$ \\
\hline Mentum, lateral scars & Large and rounded & Small and rounded & Large and oval & Large and slightly oval \\
\hline Pronotum, inferobasal pubescence & Absent & Absent & Present & Absent \\
\hline Mesosternum, scars & $\begin{array}{l}\text { Triangular, shallow, matte, with micro } \\
\text { bristles on the surface }\end{array}$ & $\begin{array}{l}\text { Triangular, shallow, matte, with micro } \\
\text { bristles on the surface }\end{array}$ & Absent & $\begin{array}{l}\text { Deep, oval or drop-shaped with matt } \\
\text { surface }\end{array}$ \\
\hline Metasternum, punctation & Large group on lateroposterior region & $\begin{array}{l}\text { Coarse punctures on lateroanterior } \\
\text { region and group of punctures in the } \\
\text { lateroposterior region }\end{array}$ & Small group on lateroposterior region & Small group on lateroposterior region \\
\hline
\end{tabular}

\section{Passalus (Passalus) cleidecostae sp. nov. (Figs. 4, 5, 6A-C)}

Type material: HOLOTYPE: $\sigma^{\star}$ (INPA). "BRAZIL. Acre: Sena Madureira / Tr23n - praia redonda / 0909'36.15"S, 6845'47.33"W / 15-19.xi.2010 / FBP Gouveia, GC de Sá col". PARATYPES: "Sena Madureira / Tr23n - praia redonda / 0909'36.15"S, 6845'47.33"W / 15-19.xi.2010 / FBP Gouveia, GC de Sá col. (1 \&, INPA). Sena Madureira / $\operatorname{Tr} 22 \mathrm{n}$ - praia redonda / $09^{\circ} 09^{\prime} 41.15^{\prime \prime} \mathrm{S}, 68^{\circ} 45^{\prime} 49.42^{\prime \prime} \mathrm{W} /$ 15-19.xi.2010 / FBP Gouveia, GC de Sá col. (1 $\sigma^{7}, 2$ \%, INPA). Sena Madureira / Tr21n - praia redonda / 0909'47.84"S, 6845'49.57"W / 15-19.xi.2010 / FBP Gouveia, GC de Sá col. (1 $\sigma^{\prime \prime}, 1$ \& INPA). Sena Madureira / Tr27n - praia redonda / 0909'27.90"S, 6845'44.30"W / 15-19.xi.2010 / FBP Gouveia, GC de Sá col. (1 $\sigma^{0}, 1$ \&, INPA). Sena Madureira / Tr30n - praia redonda / 09 $09^{\prime} 34.70^{\prime \prime S}, 68^{\circ} 45^{\prime} 41.34^{\prime \prime} \mathrm{W}$ / 15-19.xi.2010 / FBP Gouveia, GC de Sá col. (2 \&, INPA). Sena Madureira / Tr29n - praia redonda / 0909'34.70"S, 6845'41.34"W / 15-19.xi.2010 / FBP Gouveia, GC de Sá col. (2 ㅇ, INPA). Sena Madureira / roça D. [ona] Marina / (2 o', INPA)."

Diagnosis: medium sized specimens $(28-31 \mathrm{~mm}$, total length); body flat; anterior frontal edge of the front straight; anterior mediofrontal area with coarse punctures, posterior mediofrontal area with large rounded cephalic nodule; laterofrontal tubercles large, conspicuous, with acute apices; mediofrontal tubercles with rounded apices, smaller than laterofrontal tubercles, located externally to these; secondary mediofrontal tubercles smaller than laterofrontal, with acute apices, distance between them less than distance to laterofrontal tubercles; inner tubercles small, but slightly detached from the anterofrontal ridges; posterofrontal ridges elevated, strong and slightly straight, starting at apex of central tubercle; anterofrontal ridges arched, larger, lower and weaker than posterofrontal ridges; central tubercle flat, with not free apex; conspicuous and slightly rounded lateroposterior tubercles; lateropostfrontal areas with a few small punctures; mentum with non-dilated mediobasal area, large and deep lateral scars; pronotum with anterior angles not protruded and slightly acute; pronotal punctures only on marginal grooves and near lateral fossae; mesosternal scars deep and elongated; metasternal disc barely delimited, without carina, with large group of punctures on posterior region; metasternal grooves deep and pubescent; in ventral view, aedeagus ventrally with basal piece fused to parameres, and with V-shaped emargination in middle region; median lobe globular occupying almost half of all aedeagus, with two longitudinal sclerotized plates located near outer edges; in dorsal view, apices of parameres very close to each other.

\section{Description}

Body (Figs. 4-6): flat; size: medium (28-31 mm, total length).

Head (Figs. 4A-C, 5A-C, 6A): Labrum concave on anterior border. Clypeus: hidden under frons, with anterior angles small and obtuse and positioned below laterofrontal tubercles. Anterior frontal edge: straight. Secondary mediofrontal tubercles: small, smaller than laterofrontal tubercles, with acute apices, near to each other than distance to laterofrontal tubercles. Laterofrontal tubercles: large, conspicuous, with acute apices projected forward. Mediofrontal tubercles: small, with rounded apices, smaller than laterofrontal tubercles, located near and externally to this. Secondary laterofrontal tubercles: absent. Mediofrontal area: caliciform 2.1× wider than long, with anterior region deeper than posterior; with coarse punctures scattered across anterior region. Cephalic nodule: large, well-marked, rounded. Inner tubercles: small, but detached from the anterofrontal ridges, with rounded apices, a little closer to the central tubercle. Anterofrontal ridges: arched, larger, lower and weaker than the posterofrontal ridges. Posterofrontal ridges: elevated, strong and slightly straight, starting in apex of central tubercle. Central tubercle: conical, flat, with apex not free, dilated posteriorly. Lateroposterior tubercles: conspicuous, with evident apices, slightly rounded, slightly distant from cen- 
tral tubercle. Laterofrontal areas: slightly flat and smooth, without punctures or wrinkles. Lateropostfrontal areas: deep, with smooth surface containing some punctures.
Postfrontal area: shallow, smooth surface. Postfrontal groove: well-marked, lacking medial notch. Epicranial sutures: well-marked. Epicranial pits: deep. Anterior angles of

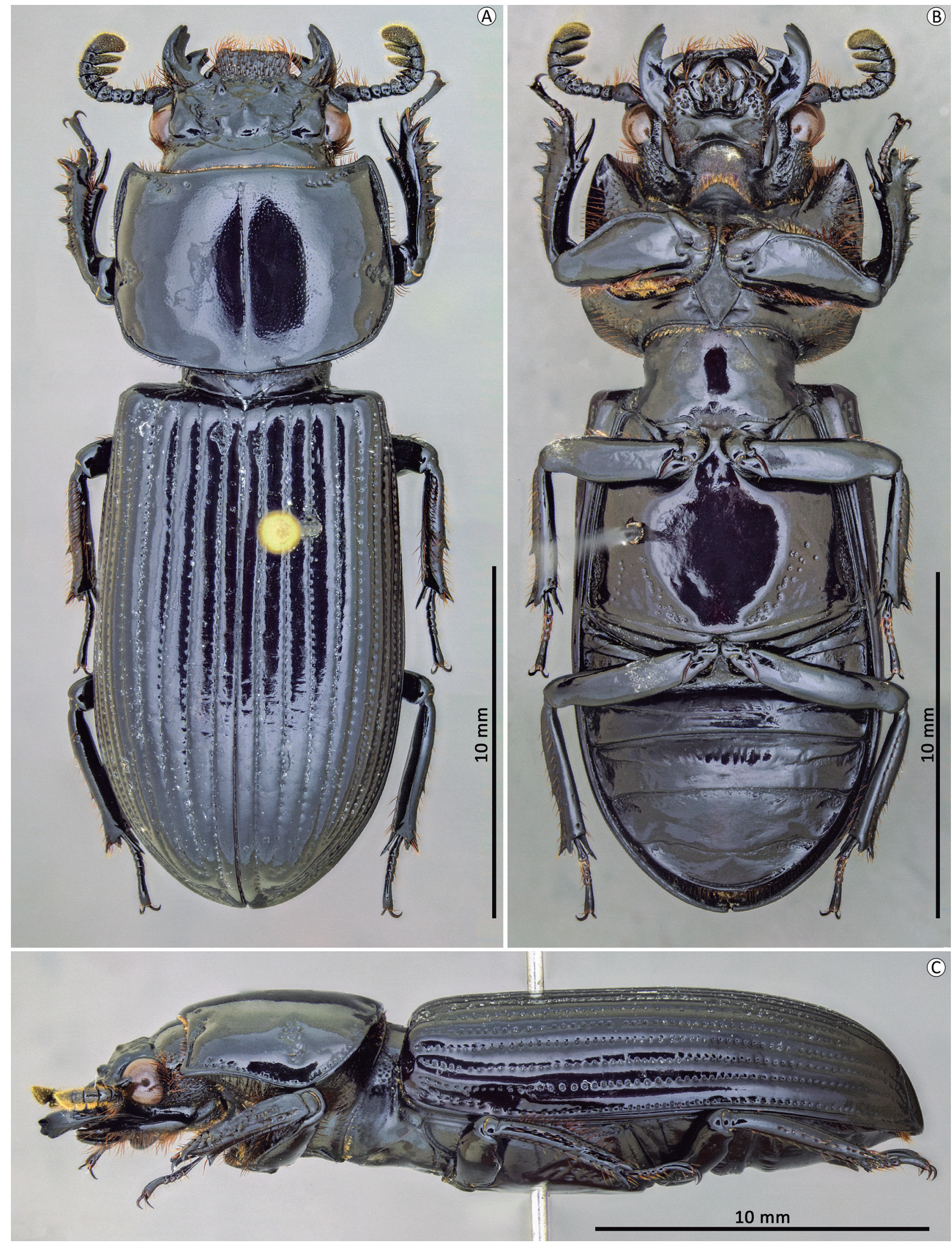

Figure 1. Passalus (Pertinax) deuterocerus sp. nov., habitus. (A) dorsal; (B) ventral; (C) lateral. 
head: well-developed, with acute apices, slightly smaller than laterofrontal tubercles. Canthus ocular: apices almost straight, not reaching half of eye. Antennae: trilamellated, with large and robust lamellae not folded inward, distal lamella almost twice as wide as the other two.

Mouthparts (Fig. 4B): Ligula: tridentate, with median tooth larger than lateral teeth. Hypostomal process: wide, glabrous, slightly close to mentum. Mentum: mediobasal area not dilated, smooth and glabrous, with slightly protruded anterior region, and median notch; lateral lobes with rounded apices; lateral scars large, deep, glabrous, unpunctate and rounded. Mandibles: incisor lobe with three well-formed apical teeth; suprainternal teeth robust; infrabasal pits inconspicuous. Maxilla: lacinia bidentate at apex.

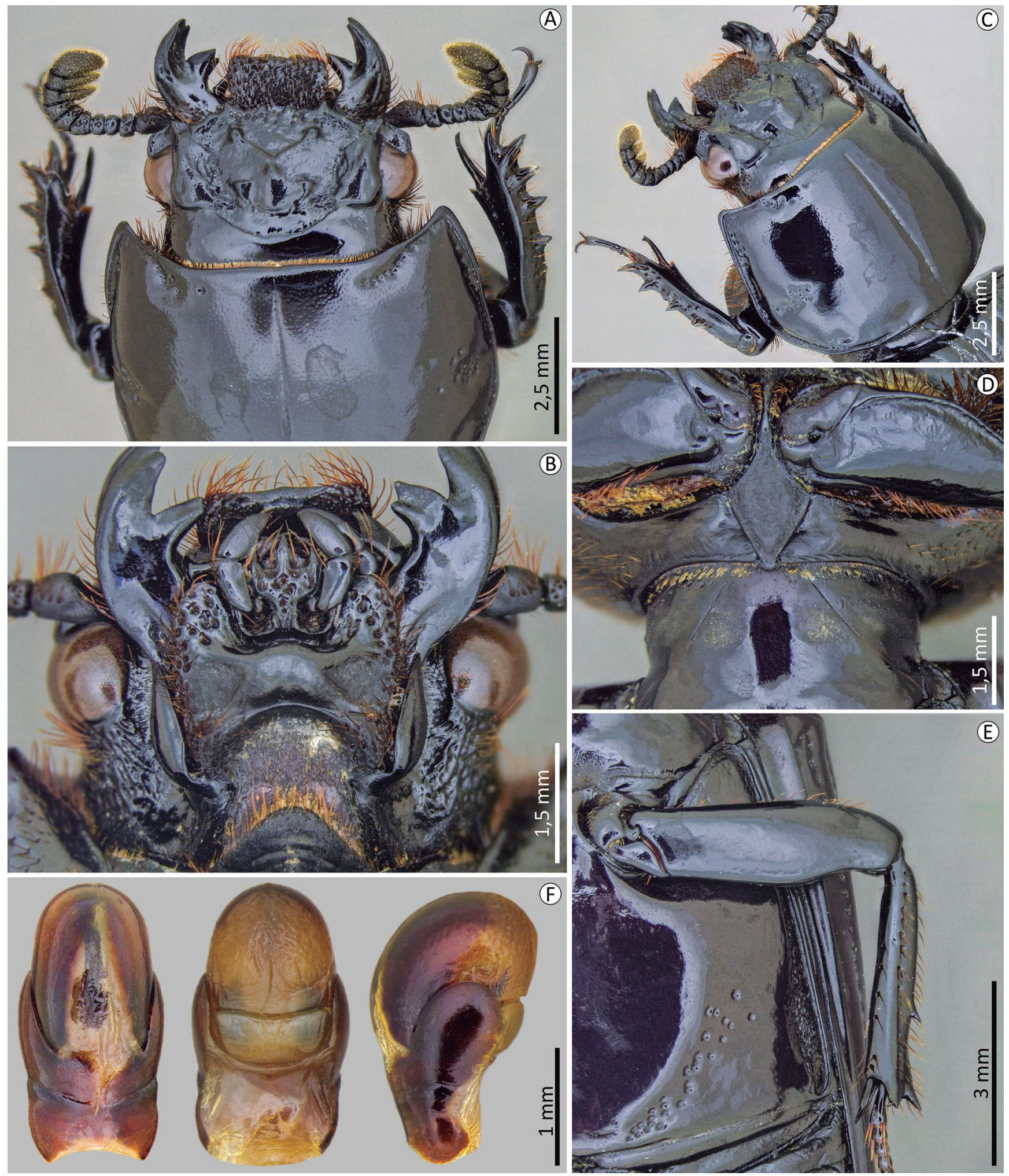

Figure 2. Passalus (Pertinax) deuterocerus sp. nov. (A) head and prothorax, dorsal; (B) head, ventral; (C) head and prothorax, dorsolateral; (D) posterior region of the prosternum and anterior region of the mesosternum; (E) metasternum (left side); (F) aedeagus (ventral, dorsal and lateral view). 
Prothorax: Pronotum (Figs. 4A, 5A, C, 6B): anterior edge slightly straight; anterior angles slightly acute and not protruding; marginal groove well-marked, deep, narrow and punctate throughout, with apex dilated, not reaching $1 / 3$ of pronotal width; lateral fossae large, well-marked, deep and rounded; with group of coarse punctures only in the region near the lateral fossae. Prosternum (Fig. 4B): prepisternum with a few long, sparse setae on outer face; prepimerum with a few sparse bristled punctures; prosternelum rhomboidal, with acute base.

Mesosternum (Figs. 4B, 5D, 6C): smooth and glabrous; mesosternal scars elongated, deep, with slightly rough surface, without punctures or pubescence.
Metasternum (Figs. 4B, 5E, 6C): disc well-delimited by weak lateral carina formed by large group of punctures on lateroposterior region of metasternal disc, almost reaching metasternal lateral groove; with bristled punctures on lateroanterior region; lateral groove narrower than mesotibiae, deep, with dense bristled punctures.

Elytra (Fig. 4A): Approximately $2.5 \times$ longer and $1.1 \times$ wider than pronotum; striae: narrower than interstriae, marked by circular punctures, on dorsal striae smaller than that on lateral striae; epipleura with setae on region closest to the humeri which have a tuft of long setae.

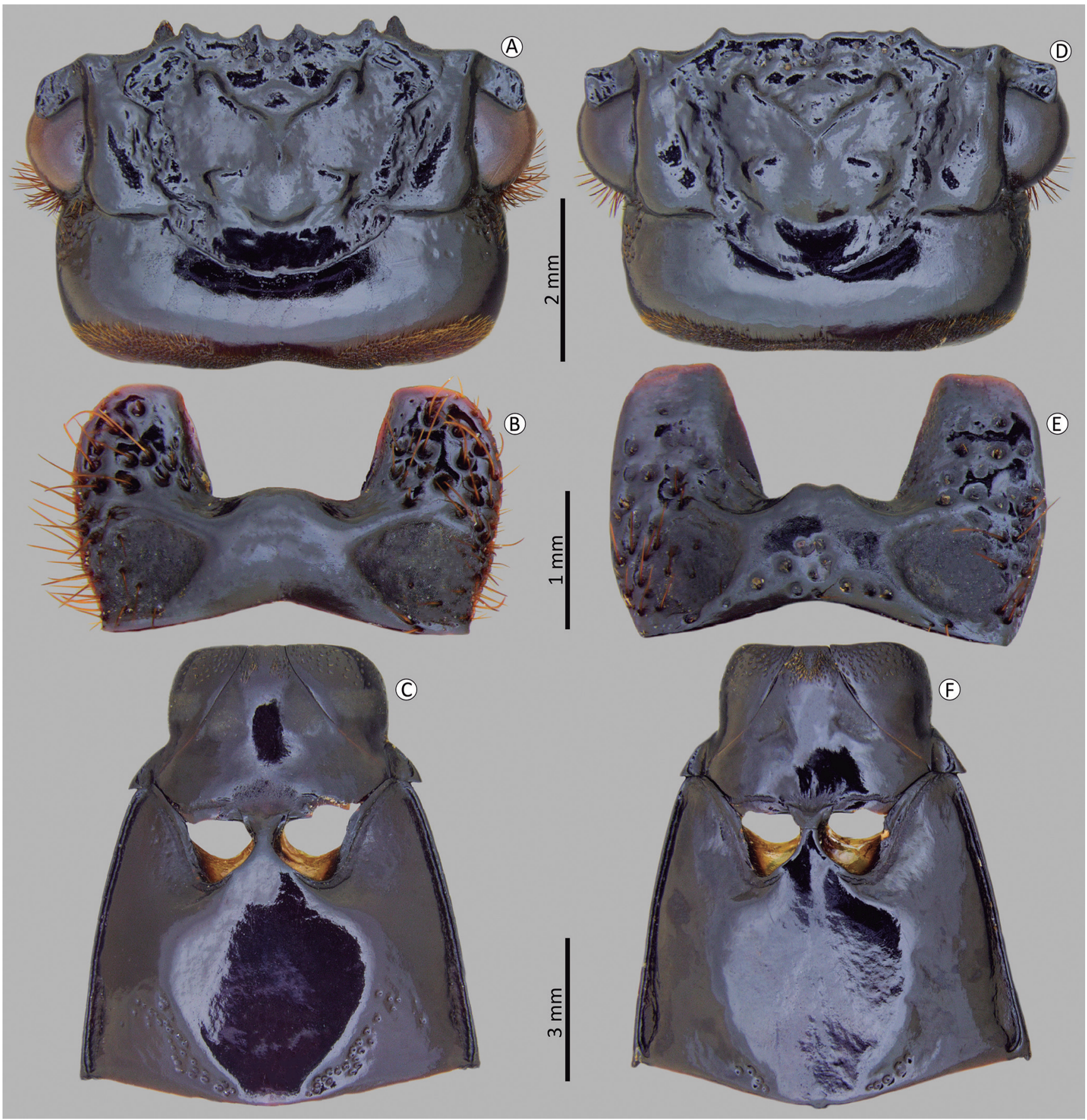

Figure 3. Passalus (Pertinax) deuterocerus sp. nov. (A) cephalic capsule, dorsal; (B) mentum; (C) meso- and metasternum. Passalus (Pertinax) epiphanoides (Kuwert, 1891): (D) cephalic capsule, dorsal. (E) mentum. (F) meso- and metasternum. 
Legs (Figs. 4A-C, 5A, C, E): profemur with well-marked groove on anteroventral border; posteroventral border with a few setae near apex; protibia not dilated; mesotibiae with one small spine on outer face; metatibiae without spine on outer face.

Abdomen (Fig. 4B): sternite VII with complete and wellmarked groove; sides rough.

Aedeagus (Fig. 5F): Median lobe: narrower than parameres and basal piece together; ventrally with two sclerotized plates lacking at median region. Basal piece attached to the parameres forming a tegmen. Tegmen ventrally with median anterior region with $\mathrm{V}$-shaped median notch; laterally, with slightly straight projections almost reaching half-length of median lobe; dorsally, with projections attached.

Etymology: We dedicate this new species to Dr. Cleide Costa, a researcher with extensive career in Coleoptera systematics, working especially with Neotropical immature insects and for her dedication on training taxonomists.

Polymorphisms: The size of the inner tubercles, and the density of punctures on the lateropostfrontal areas may vary.

Remarks: Passalus cleidecostae sp. nov. can be assigned to subgenus Passalus (Passalus), precisely in the "Neleus" section by the following characters: mediofrontal area short and transverse; presence of two well-developed secondary mediofrontal tubercles; mediofrontal and laterofrontal tubercles not fused, but close together; inner tubercles small; metasternal disc well-delimited, and humeri, epipleura, lateroanterior region of the metasternum and metasternal groove pubescent. It is more similar to species whose apex of the central tubercle is not free, such as P. interstitialis Eschscholtz, 1829 and $P$. bucki Luederwaldt, 1931. The new species differs from $P$. interstitialis by presenting smaller and more obtuse secondary mediofrontal tubercles; smaller mediofrontal tubercles and not overlapping laterofrontal tubercles; less developed inner tubercles; less straight frontal ridges; shorter and thicker antennal lamellae, not turned inwards; weaker carina on metasternal disc, and sparser pubescence on the humeri, epipleura, and metasternal anterolateral region (Table 2). The similarities with $P$. bucki are more pronounced, since both species have secondary mediofrontal tubercles smaller than laterofrontal tubercles, and with obtuse apices, presence of punctures on anterior mediofrontal and lateropostfrontal areas. However, they can be differentiated since $P$. cleidecostae sp. nov. presents secondary mediofrontal tubercles with more acute apices (Figs. 6A, D), inner tubercles larger and more conspicuous (Figs. 6A, D), frontal ridges smooth (Figs. 6A, D), anterior mediofrontal and lateropostfrontal areas with smaller and sparser punctures (Figs. 6A, D), pronotal punctures concentrated only near the lateral fossae (Figs. 6B, E), and metasternal punctures not ex- ceeding the lateroposterior region of the metasternal disc (Figs. 6C, F) (Table 2).

Although $P$. cleidecostae sp. nov. and $P$. bucki are similar species, they have enough distinctive characteristics, which was possible to see after comparison with the P. bucki type series deposited at the Museu de Zoologia da Universidade de São Paulo (MZUSP), as well as specimens from other localities and species that also belong to the Neleus section. Both species may be more similar, since the presence of flattened central tubercle flatted, and absence of free apex are not common characteristics in this group. It is possible that within the Neleus section these species form a group which the main characteristic is related to the central tubercle.

\section{DISCUSSION}

As previously discussed by Bevilaqua \& Fonseca $(2017,2019)$, the western region of the Brazilian Amazon, especially the westernmost part, is considered a very rich and diverse area for numerous taxa, including Passalidae, when compared to other well-studied areas of the Brazilian Amazon, and bordering countries. In this region, as well as throughout South America, the genus Passalus stands out for its great diversity, and although the literature has already pointed out that this genus may be polyphyletic (Reyes-Castillo, 1970; Boucher, 2006; Jiménez-Ferbans et al., 2016a), the researchers on Passalidae often use the classification initially proposed by Luederwaldt (1931), since so far no systematic study has been conducted to better delimit the groups present in Passalus. However, it is expected that this species-rich genus will undergo changes in its classification over the next few years, as a systematic work is underway.

The current composition was initially proposed by Gravely (1918) who, in his worldwide review, synonymized all genera included in the subfamilies Pertinacinae, Rhodocanthopinae, Pleurariinae (except Pleurarius Kaup, 1868), Neleidinae, Phoronaeinae, Petrejinae, Vatiniinae and Neleinae defined in the classification proposed by Kuwert (1898) as well as the genera Eumelus Kaup, 1871, and Mitrorhinus with Passalus (which according to Gravely (I.c.) was considered a "complex and heterogeneous genus"). The author stated that, despite proposing such synonyms, he is not sure if they are valid for some genera. Years later, his proposal was implemented by Luederwaldt (1931), who proposed subdividing Passalus into three subgenera based mainly on the presence and quantity of secondary mediofrontal tubercles, and subdividing Passalus (Passalus) into groups of species called sections. Following the proposals of Gravely (I.c.) and Luederwaldt (I.c.), Hincks (1933, 1934, 1935) and Hincks \& Dibb $(1935,1958)$ carried out works to reassess this genus, proposing synonyms and nomenclatural corrections, which culminated in the only catalog (Hincks \& Dibb (I.c.)) that lists all Passalus species, their synonyms and distributions. Reyes-Castillo (1970) redescribed the genus and commented that it is necessary to reevaluate the characters used to distinguish subgenera. 
Thus, by analyzing the material from various regions of the New World, especially the Amazon region, and based on previous works, it is possible to make two comments:

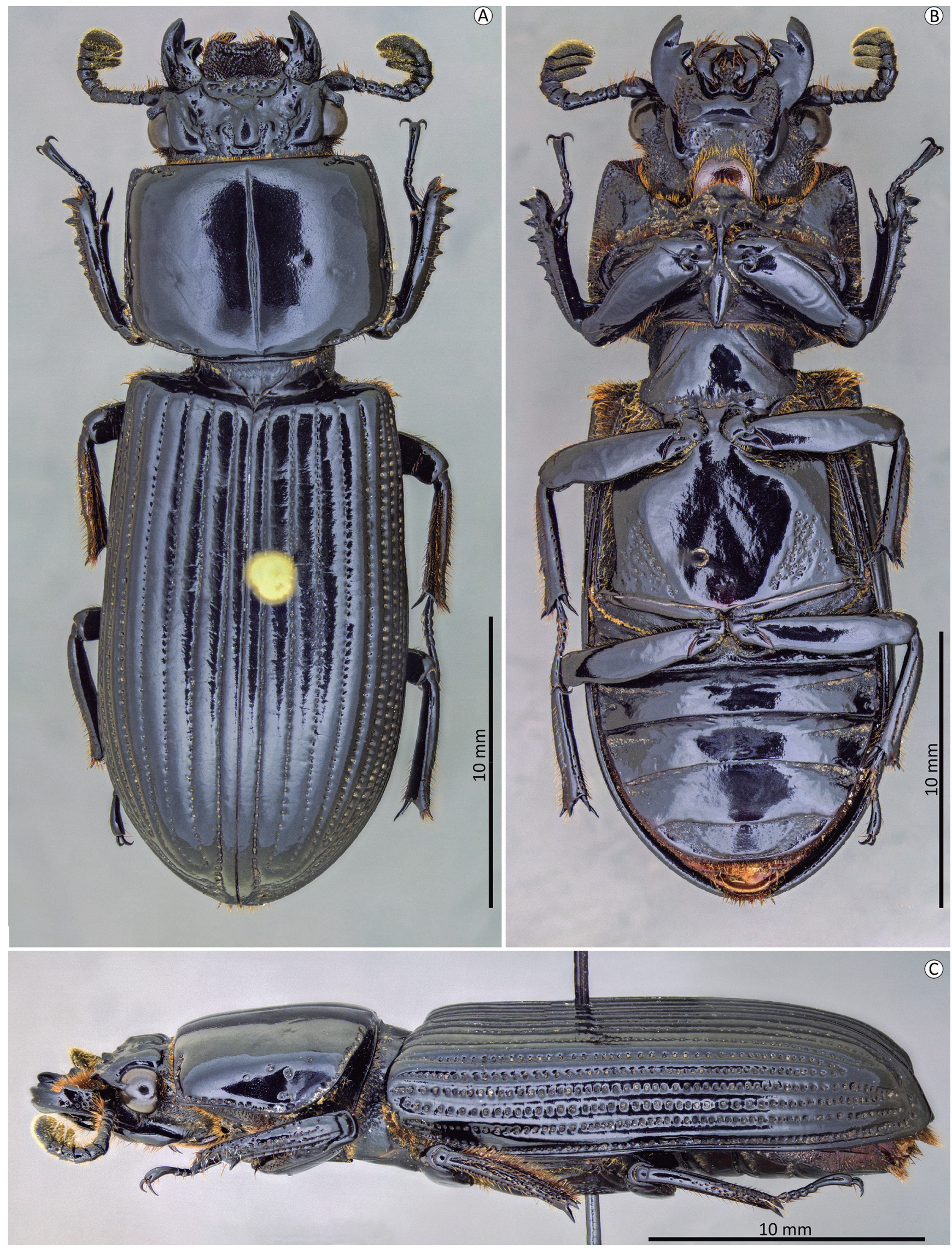

1. The number of valid Passalus species is still doubtful, since several species need to be revalidated and others synonymized. However, considering the last

Figure 4. Passalus (Passalus) cleidecostae sp. nov., habitus. (A) dorsal; (B) ventral; (C) lateral. 
species described in Jiménez-Ferbans et al. (2019) and the new status of $P$. occidentalis Hincks, 1950 (Bevilaqua \& Fonseca in press) Passalus comprises 171 species (including the two new species described here), 81 of which in P. (Pertinax), 11 in P. (Mitrorhinus), and 79 in P. (Passalus). Within P. (Passalus), 21 species are allocated in Phoroneus section, 33 in Petrejus section, and 25 in Neleus section.
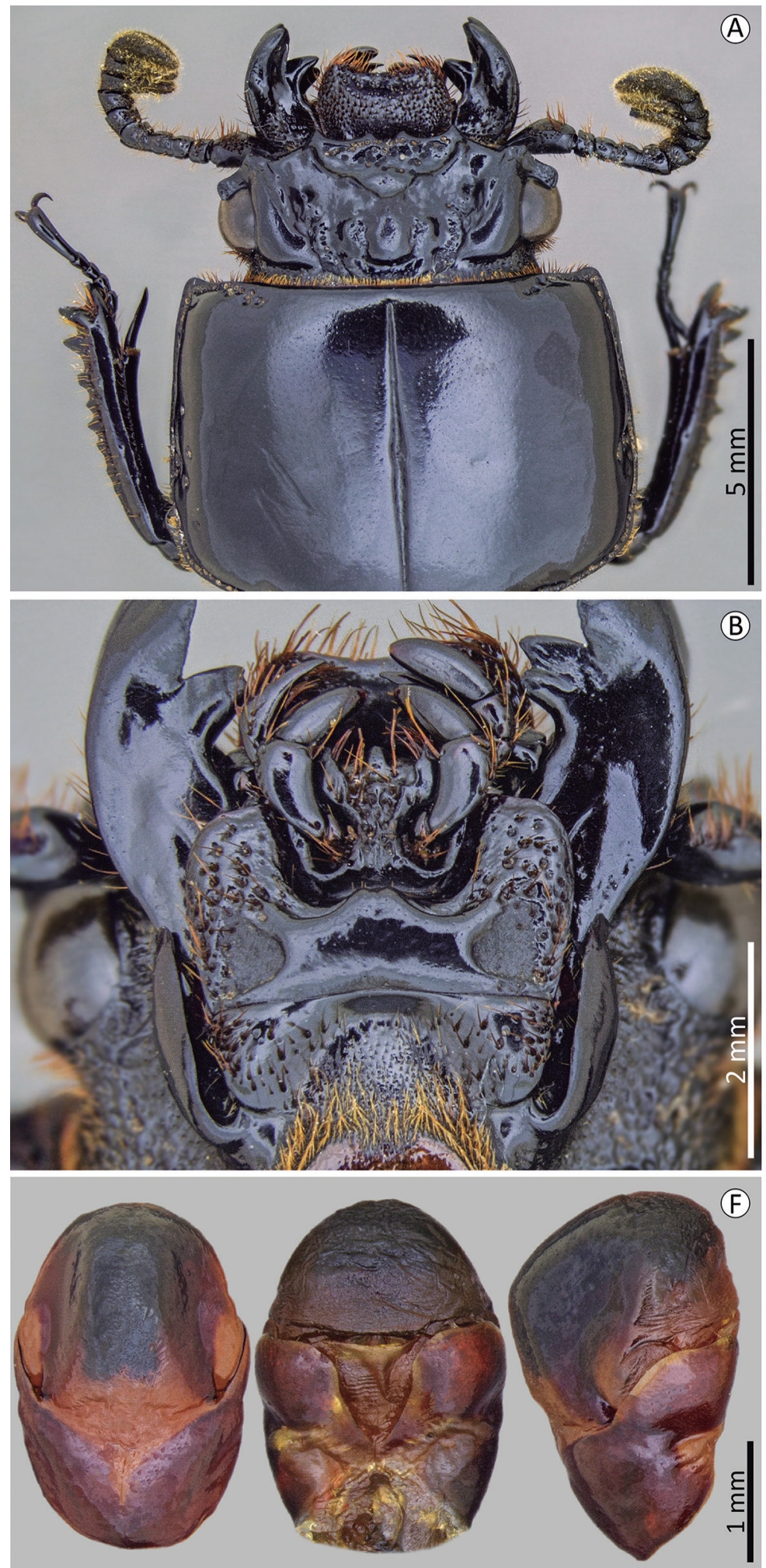

(F)
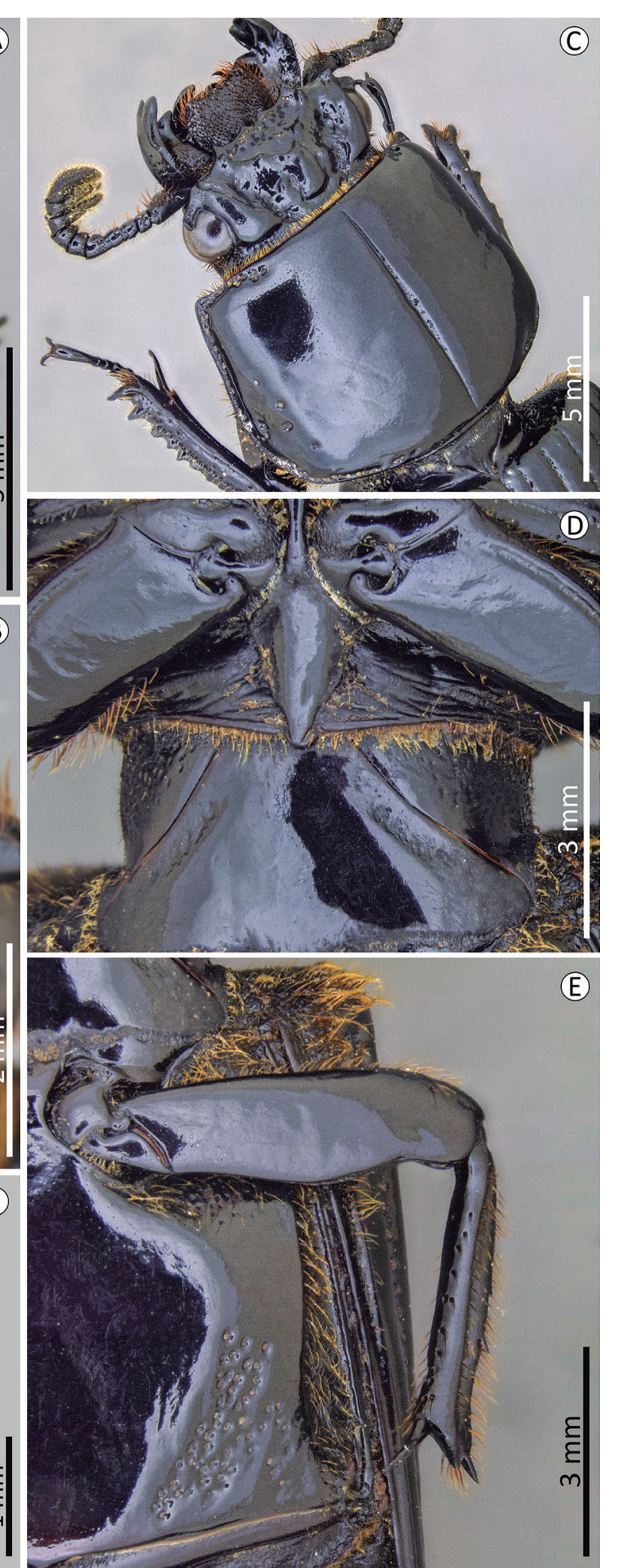
terize them: usually $P$. (Pertinax) presents body convex; anterior frontal edge straight, without secondary mediofrontal tubercles (except in some species such as $P$. deuterocerus sp. nov. and those belonging to the Rhodocanthopus group); posterofrontal ridges usu-

Figure 5. Passalus (Passalus) cleidecostae sp. nov. (A) head and prothorax, dorsal; (B) head, ventral (C) head and prothorax, dorsolateral; (D) posterior region of the prosternum and anterior region of the mesosternum; (E) metasternum (left side); (F) aedeagus (ventral, dorsal and lateral view). 
ally strong and high, reaching the well-developed inner tubercles, which are located midway between the central tubercle and the latero + mediofrontal tubercles; mesosternal scars usually small and shallow, sometimes absent; metasternal grooves narrow and glabrous (except in some species, like $P$. mancus Burmeister, 1847, P. matilei (Boucher, 2000) and P. loici (Boucher, 2000)), and the metasternal disc is barely marked by a carina or punctures.

Passalus (Mitrorhinus) is characterized by having a single secondary mediofrontal tubercle in anterior frontal edge, which may be split or not at the apex; anterofrontal ridges which, although weak in some species, reach the latero + mediofrontal tubercles; scarce pubescence on body; and metasternal disc barely delimited by a carina or punctures, with narrow and glabrous metasternal groove.

Overall, $P$. (Passalus) is complex to define, but it can be characterized by having none or two secondary mediofrontal tubercles and, when present, they may be near each other and small, or large and distant from each other; concave or straight frontal edge of the labrum; and dense pubescence present or not on body. The sections

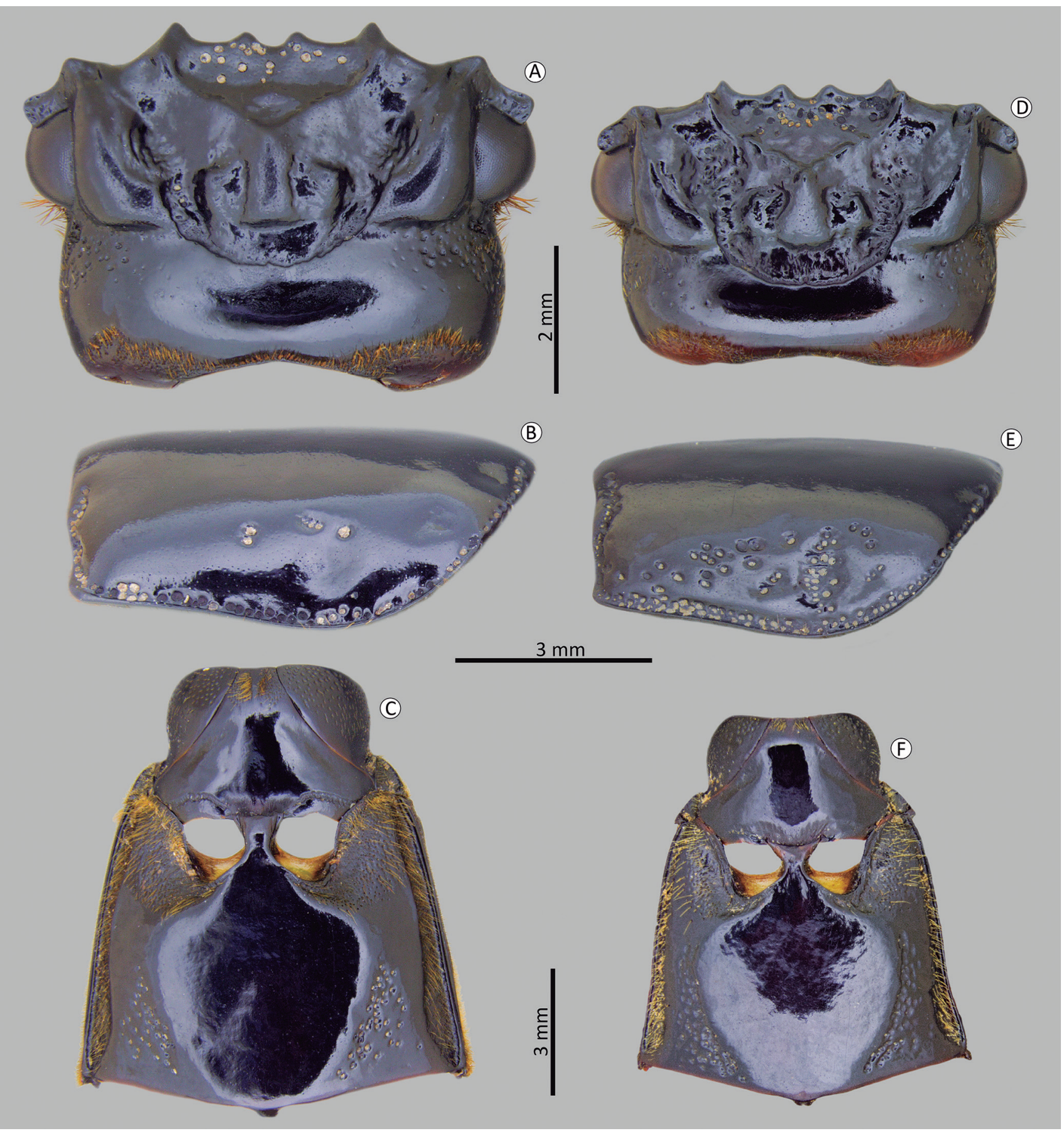

Figure 6. Passalus (Passalus) cleidecostae sp. nov. (A) cephalic capsule, dorsal; (B) pronotum, lateral; (C) meso- and metasternum. Passalus (Passalus) bucki Luederwaldt, 1931: (D) cephalic capsule, dorsal v. (E) pronotum, lateral. (F) meso- and metasternum. 
Table 2. Differential characters of Passalus cleidecostae sp. nov., P. interstitialis Eschscholtz, 1829 and P. bucki Luederwaldt, 1931.

\begin{tabular}{|c|c|c|c|}
\hline Characters / Species & P. cleidecostae sp. nov. & P. interstitialis & P. bucki \\
\hline Frons, mediofrontal area & Slightly punctated on anterior region & Slightly punctated on anterior region & Quite punctated with coarse punctuation \\
\hline Frons, secondary mediofrontal tubercles & $\begin{array}{l}\text { Small, smaller than laterofrontal tubercles, with } \\
\text { acute apices close to each other }\end{array}$ & $\begin{array}{l}\text { Large, sometimes larger or with same size as } \\
\text { laterofrontal tubercles, with acute apices close } \\
\text { to each other }\end{array}$ & $\begin{array}{l}\text { Small, smaller than laterofrontal tubercles, with } \\
\text { obtuse apices close to each other }\end{array}$ \\
\hline Frons, mediofrontal tubercles & $\begin{array}{l}\text { Small, smaller and non-overlapping to } \\
\text { laterofrontal tubercles }\end{array}$ & $\begin{array}{l}\text { Large, larger and overlapping to laterofrontal } \\
\text { tubercles }\end{array}$ & $\begin{array}{l}\text { Small, smaller and non-overlapping to } \\
\text { laterofrontal tubercles }\end{array}$ \\
\hline Frons, inner tubercles & Small and detached from the frontal ridges & Large and detached from front ridges & Small and not detached from the frontal ridges \\
\hline Frons, anterofrontal ridges & Large, low and arched & Absent or inconspicuous & Large, low and crenulated \\
\hline Frons, posterofrontal ridges & $\begin{array}{l}\text { Smaller, straighter and more elevated than } \\
\text { anterofrontal ridges }\end{array}$ & $\begin{array}{l}\text { Larger, straighter and more elevated than } \\
\text { anterofrontal ridges }\end{array}$ & $\begin{array}{l}\text { Smaller, straighter and more elevated than } \\
\text { anterofrontal ridges }\end{array}$ \\
\hline Vertex, lateropostfrontal areas & Presence of some small punctures & Absence of punctation & Presence of many coarse punctures \\
\hline Pronotum, punctation & $\begin{array}{l}\text { Reduced to a small group of punctures near the } \\
\text { lateral fossae }\end{array}$ & $\begin{array}{l}\text { Group of punctures scattered throughout lateral } \\
\text { region }\end{array}$ & $\begin{array}{l}\text { Group of punctures scattered throughout lateral } \\
\text { region }\end{array}$ \\
\hline Metasternum, punctation & $\begin{array}{l}\text { Group of punctures on lateroposterior region and } \\
\text { bristled punctures on anterior region }\end{array}$ & $\begin{array}{l}\text { Group of punctures concentrated throughout the } \\
\text { region of the metasternal carina, and bristled } \\
\text { punctures on anterior region }\end{array}$ & $\begin{array}{l}\text { Group of punctures concentrated throughout the } \\
\text { region of the metasternal carina, and bristled } \\
\text { punctures on anterior region }\end{array}$ \\
\hline
\end{tabular}

have greater uniformity of characters. Species belonging to the Phoroneus section often have small secondary mediofrontal tubercles close to each other, and often with obtuse apices; scarce body pubescence; metasternal disc barely delimited by a carina or punctures, and narrow and glabrous metasternal fossae. The Petrejus section is the most heterogeneous group, including species with body convex, which have a large and very free apex central tubercle and, usually have no secondary mediofrontal tubercles or, when present, they are rudimentary; the posterofrontal ridges are transverse and short, and the anterofrontal ridges are generally absent; the metasternal disc is barely delimited by punctures or a carina, and the body pubescence is generally scarce. The species of Neleus section are more homogeneous, with a flattened body; large and separated secondary mediofrontal tubercles with acute apices; transverse mediofrontal area; unfused laterofrontal and mediofrontal tubercles; poorly developed inner tubercles; metasternal disc well-delimited by a carina and punctures, and body pubescence quite dense.

The delimitation of the subgroups and species belonging to Passalus has been a much-discussed issue in recent works (Boucher, 2006, 2015a, b, c; JiménezFerbans et al., 2015, 2016a, b, 2017, 2018; Bevilaqua \& Fonseca, 2017, 2019) and this has been the main focus of the authors of this work in recent years, therefore, as mentioned earlier, this genus is expected will undergo changes in its classification, facilitating the delimitation of its species groups, making it better grounded. In view of this, in the future, further analysis of materials from Brazilian and foreign collections will be conducted in order to gather more information on the biodiversity of Passalus in the Amazon.

\section{ACKNOWLEDGMENTS}

We would like to thank Dr. Sônia Casari, Coleoptera session curator of the Museu de Zoologia da Universidade de São Paulo, for allowing us to examine the Passalus bucki type material, and MSc. Fabio Godoi, curator of the Coleção Zoológica Professor Paulo Bürhnheim of the Universidade Federal do Amazonas, for allowing us to examine the Passalus material. To the editors Dr. Sônia Casari and Dr. Gabriel Biffi for the invitation to participate in this Special Volume. To Dr. Gabriel Biffi and two anonymous reviewers for providing important considerations to the article. The first author thanks CAPES by the doctorate scholarship by the CNPq/MCTI/FAP/PROTAX № 001/2015 process CNPq: 440532/2015-9.

\section{REFERENCES}

Bevilaqua, M. \& Fonseca, C.R.V. 2019. Passalidae (Coleoptera: Scarabaeoidea) from the West-Most Brazilian Amazon Region: Checklist, New Records, and Identification Key. Neotropical Entomology, 48(3): 449-466. D0I

Bevilaqua, M.V.0. \& Fonseca, C.R.V. 2017. New species of Passalus (Mitrorhinus) Kaup, 1871 (Coleoptera: Scarabaeoidea: Passalidae) from the extreme west of the Brazilian Amazon. Acta Zoologica Mexicana Nueva Série, 33(2): 344-348. DOI

Boucher, S. 2006. Evolution and phylogeny of Passalidae (Scarabaeoidea). Annales de la Société Entomologique de France, N. S., 41(3/4): 239-604, 2005.

Boucher, S. 2015a. Splitting of the polyphyletic genus Passalus Fabricius, s. auct. (Coleoptera, Passalidae). Bulletin de la Société entomologique de France, 120(1): 113-120.

Boucher, S. 2015b. Les trois Passalus F. s. str. des Petites Antilles, de I'Archipel de la Guadeloupe à Grenade (Coleoptera, Passalidae). Coléoptères, 21(2): 19-34.

Boucher, S. 2015c. Homology versus homoplasy, a case of comprehensive study of male genitalia to reconstruct phylogeny of Passalidae of the Greater Antilles (Coleoptera, Scarabaeoidea). Coléoptères, 21(1): 1-17.

Fonseca, C.R.V. \& Reyes-Castillo, P. 2004. Synopsis on Passalidae family (Coleoptera: Scarabaeoidea) of Brazil with description of a new species of Veturius Kaup, 1871. Zootaxa, 789: 1-26.

Fonseca, C.R.V.; Barbosa, M.L.L. \& Fernandez, M.F.S. 2011. A hypothetical evolutionary history of passalid beetles narrated by the comparative anatomy of the hindgut (Coleoptera: Passalidae). Zootaxa, 3012: 1-20.

Gravely, F.H. 1918. A contibution towards the revision of the Passalidae of the world. Memoirs of the Indian Museum, 7(1): 1-143. 
Hincks, W.D. 1933. Notes on the Passalidae. No. 3. New synonymy and some little-known species with the description of a new Publius. The Entomologist's Monthly Magazine, 69: 175-182.

Hincks, W.D. 1934. Notes on the Passalidae (Coleoptera). No. 5. Synonymic notes, with the descriptions of a new genus and new species. The Entomologist's Monthly Magazine, 70: 151-157; 270-274.

Hincks, W.D. 1935. Notes on the Passalidae (Coleoptera). No. 5. Synonymic Notes, with the descriptions of a new Genus and new Species. The Entomologist's Monthly Magazine, 71: 50-54.

Hincks, W.D. \& Dibb, J.R. 1935. Coleopterorum catalogus. Pars 142: Passalidae. s'Gravenhage, W. Junk. 118p.

Hincks, W.D. \& Dibb, J.R. 1958. Coleopterorum catalogus. Suplementa Pars 142: Passalidae. s'Gravenhage, W. Junk. 32p.

Jiménez-Ferbans, L.; Reyes-Castillo, P. \& Schuster, J.C. 2015. Passalidae (Coleoptera: Scarabaeoidea) of the Greater and Lesser Antilles. Zootaxa, 3956(4): 491-512.

Jiménez-Ferbans, L.; González, M.D. \& Reyes-Castillo, P. 2016a. Phylogeny and species delimitation in the group Rhodocanthopus of the genus Passalus (Coleoptera: Passalidae) inferred from morphological and molecular data, with description of two new species. Arthropod Systematics and Phylogeny, 74(3): 255-266.

Jiménez-Ferbans, L.; Reyes-Castillo, P.; Schuster, J.C. \& Upegui-Vélez, C. 2016b. Passalus coarctatus Percheron, 1835 (Coleoptera: Passalidae): redescripción y nuevos registros distributivos. Acta Zoológica Mexicana, Nueva Serie, 32(2): 168-173. D01
Jiménez-Ferbans, L.; Reyes-Castillo, P.; Schuster, J.C. \& Beza-Beza, C. 2017. The passalid beetles (Coleoptera: Passalidae) from Costa Rica, with the description of two new species of Passalus. Revista Mexicana de Biodiversidad, 88(3): 608-615. D0I

Jiménez-Ferbans, L.; Reyes-Castillo, P.; Schuster, J.C. 2018. Passalidae (Coleoptera: Scarabaeoidea) of the Biogeographical Province of Chocó and the West Andean Region of Colombia, with the Description of Two New Species. Neotropical Entomology, 47(5): 642-667. D01

Jiménez-Ferbans, L.; Reyes-Castillo, P.; Schuster, J.C. 2019. The Passalidae (Coleoptera, Scarabaeoidea) from Bolivia, with the descriptions of three new species. ZooKeys, 882: 51-85. DOI

Kawada, R. \& Buffington, M.L. 2016. A scalable and modular dome illumination system for scientific microphotography on a budget. PLOS One, 11(5): e0153426. D0I

Kuwert, A. 1898. Die Passaliden Dichotomisch Bearbeitet. Novitates Zoologicae, 5: 137349.

Luederwaldt, H. 1931. Monografia dos passalídeos do Brasil (Col.). Revista do Museu Paulista, 17: 1-262.

Reyes-Castillo, P. 1970. Coleoptera, Passalidae: morfología e división en grandes grupos; géneros Americanos. Folia Entomolica Mexicana, 20-22: $1-240$.

Reyes-Castillo, P. 1973. Passalidae de la Guayana Francesa (Coleptera, Lamellicornia). Bulletin du Museum National d'Histoire Naturelle, Série Zoologie, 129(197): 1541-1587.

Schuster, J.C. \& Cano, E.B. 2008. Taxonomy of Passalidae of the New World. Available at:http://unsm-ento.unl.edu/Guide/Scarabaeoidea/Passalidae/ Passalidae-Taxonomy.pdf. Access in: 04/02/2020. 